\title{
VOLUNTARY EMISSION REDUCTIONS, SOCIAL REWARDS, AND ENVIRONMENTAL POLICY
}

\author{
MICHAEL RAUSCHER
}

CESIFO WORKING PAPER NO. 1838

CATEGORY 8: RESOURCES AND ENVIRONMENT

NOVEMBER 2006

An electronic version of the paper may be downloaded

- from the SSRN website:

- from the RePEc website:

- from the CESifo website:

www.SSRN.com

www.RePEc.org

www.CESifo-group.de 


\title{
VOLUNTARY EMISSION REDUCTIONS, SOCIAL REWARDS, AND ENVIRONMENTAL POLICY
}

\begin{abstract}
Social norms and intrinsic motivations lead to environmentally friendly behaviour even in the absence of environmental policy. This paper looks at the interactions of social norms and environmental regulation in their impact on individual behaviour. People obtain social rewards for voluntary abatement efforts. These social rewards may be crowded out by environmental regulation taking the shape of standards or taxes. Moreover, the paper shows that environmental externalities and externalities related to social norms interact and that an optimal environmental policy should consider both types of externalities. From a general welfare point of view, emission taxes are superior to emission standards, but people responsive to social rewards prefer standards.
\end{abstract}

JEL Code: H3, Z13, Q28.

Michael Rauscher

University of Rostock

Department of Economics

Ulmenstr. 69

18051 Rostock

Germany

michael.rauscher@uni-rostock.de 


\section{Voluntary Emission Reductions, Social Rewards, and Environmental Policy ${ }^{*}$}

Michael Rauscher

\section{Environmental Policy, Intrinsic Motivation, and Social Norms}

Most of the economic analysis of environmental problems and their solution is based on a rather narrow conception of man. Humans are being viewed as egocentric rational utility maximisers who respond to only two types of external stimuli: economic incentives and coercion. The environmental policies discussed by economists are usually directed at these two stimuli. On the one hand, there are emission taxes, abatement subsidies, and tradable pollution permits, that provide economic incentives or disincentives. On the other hand, there is the command-andcontrol approach, forcing individuals to do what they would not do voluntarily. A large literature in the field of environmental economics has been devoted to comparing the incentives and the command-and-control approaches, usually establishing the superiority of the former over the latter. Other determinants of environmentally relevant behaviour, however, have been neglected by and large. This would not be a serious omission if they were of only minor relevance. This is, however, not the case. Environmentally friendly behaviour is often observed in situations where neither economic incentives nor coercion by law are present. An example is the separate collection of different types of household waste (organic, plastic, paper, bottle, batteries, etc.), in which many people engage although there are no economic incentives and no enforced laws. Still people incur private costs storing several types of waste separately in their homes and then bringing them to particular waste containers where these materials are collected for recycling purposes. There are two possible explanations for this type of behaviour: intrinsic motivation and social norms. Either people derive some extra utility from behaving in a way they consider

\footnotetext{
* This paper was written while I participated in the project "Environmental Economics: Policy Instruments, Technology Development, and International Cooperation" conducted at the Centre for Advanced Study (CAS) at the Norwegian Academy of Science and Letters in Oslo in 2005/2006. The financial, administrative and professional support of the Centre to this project is much appreciated. Draft versions of the paper were presented in seminars at the universities of Oslo and Rostock, at CAS in Oslo and at the Vienna Instiute of Demography. I thank Kjell-Arne Brekke, Rolf Golombek, Marietta Horster, Kalle Moene, Karine Nyborg, Erik Sørensen, and Franz Wirl for helpful suggestions and critique. The usual disclaimer applies.
} 
to be environmentally friendly or responsible, or they are driven by social norms and social control. This paper is about the second aspect. ${ }^{1}$

The neglect of intrinsic motivation and socially determined behaviour by mainstream environmental economics could be justified if the economic and non-economic spheres were independent of each other, i.e. if the introduction of environmental taxes, tradable permits, and other kinds of regulation did not affect intrinsic motivation and social norms. However, this often is not the case. It is well-known, for instance, that economic incentives interfere with intrinsic motivation. A famous example is the claim that economic incentives can erode the intrinsic motivation to donate blood. See Titmuss (1971), who argues that countries in which blood donation is commercialised suffer from larger shortages in blood supply than countries in which blood is donated on a voluntary basis. Empirical evidence that monetary incentives crowd out intrinsic motivation has been provided by Gneezy/Rustichini (2000a,b) and Brekke/Kverndokk/Nyborg (2003). Mellström/Johannesson (2005) did an experiment on the effect of economic incentives on blood donation and show that women are subject to crowding-out effects, whereas men are not. Weck-Hannemann/Frey (1995) argued that the crowding out of intrinsic motivation might apply to environmentally responsible behaviour as well. Economic instruments of environmental policy, in particular if they attach a price to environmental quality, may undermine intrinsic motivation. The main reasons are that external coercion and price incentives erode self-determination and that they are often applied in a way perceived as being unfair by the regulatees. ${ }^{2}$

Hirsch (1976, ch. 6) has argued that similar arguments apply to socially determined behaviour. The functioning of social interactions may be eroded by the introduction of markets. This has been formalised by Holländer (1990), Kandel/ Lazear (1992) and Bénabou/Tirole (2006). Experimental research has established that

1 Social control of environmentally relevant behaviour is omnipresent in some societies. For example, Germany, and particularly Eastern Germany, is a country where the separation of household waste is taken very seriously by substantial parts of the population. Living there, the author of this paper has made his personal experiences with social control. Imagine a situation where you throw an empty wine bottle into the ordinary waste bin located in the backyard of the house you are living in. A window in the neighbouring five story house opens and a voice starts yelling at you telling you that you should get this bottle out of this waste bin and bring it to the glass container located some three blocks down the street. Many people would not care about this, but as a German, you start feeling guilty. Social control has worked.

2 See Frey $(1986,1992,1993)$ for a more general discussion of this idea. In Frey (1992), a simple formalisation of the phenomenon of intrinsic motivation is given in the framework of a utility maximisation model. 
social norms and social rewards really play an important role in the creation of cooperative outcomes in prisoners'-dilemma-type games. See Gächter/Fehr (1999), for example. Additional empirical evidence supporting the claim of crowding out of environmentally relevant social norms by economic incentives has been reported by Cardenas/Stranlund (2000), who did an experiment with inhabitants of rural Columbia who relied on using forest resources. Their experiment consisted of two treatments, one with social interaction and the other one without social interaction, but with an environmental regulation (that was only weakly enforced). To me, this set-up seems a bit artificial since in the real world social norms and environmental regulation co-exist. This co-existence of norms and regulation will be modelled in this paper. The main questions to be answered by this paper are:

- Does environmental regulation crowd out social norms?

- Is there a difference between the effects of different types of environmental policy, in particular between market instruments and command and control?

- Can stricter environmental regulation be harmful to the environment if crowding-out effects are very strong?

- What are the rules for optimal environmental policies if social norms are relevant?

The approach is a theoretical one. I modify Holländer's (1990) model of socially rewarded contributions to a public good and apply it to an environmental-economics setting. In contrast to Holländer, who endogenises the supply of social rewards, I assume that this supply is exogenously given. On the other hand, I will allow for a more general model of the impact of social rewards on individual behaviour, where Holländer used a linear specification. Moreover, in my model agents are heterogeneous whereas they were homogenous in Holländer's model. Finally, different instruments of environmental policy are analysed and it will be seen that instrument choice matters. Another paper closely related to the present one is that by Lai/Yang/Chang (2003), who look at a model where socially responsible firms decide to comply with environmental standards even though the probability of being detected and fined as a non-compliant is small. The strength of the social norm and, therefore, the severity of social sanctions depends positively on the number of firms not violating the standard. ${ }^{3}$ As in other models of this type (e.g. tax evasion models),

3 In my view, there is logical problem here. Like legal sanctions, social sanctions require that a deviation from the norm is observable and verifiable, but in Lai/Yang/Chang (2003, p.66) social sanctions are independent of the detection of any violation of norms. Their approach may, however, be saved by arguing that deviators do not suffer from social sanctions but from a negative 
there are multiple equilibria with high and low degrees of compliance and the authors show that tighter environmental policies may increase pollution. The present paper is different from that by Lai/Yang/Chang (2003) in two major respects. Firstly, I do not consider illegal activities but concentrate on voluntary contributions. Agents do not only refrain from breaking the law; they really do more than they are required to do. Secondly, the number of voluntary contributors is exogenous. Another related paper is by Bénabou/Tirole (2006), who deal with social norms and social rewards as a signalling problem. People like to be regarded as being unselfish and prosocial, but fellow humans can only extract limited information about their true character from their behaviour. This implies that pooling takes place and that changes in economic environment such as institutions furthering the desired behaviour may be counterproductive since they attract the wrong people to the pool. In my model, pooling plays no role: the action reveals the true character of the agent. Nevertheless, this paper derives some surprising results and interesting policy implications.

The paper is organised as follows. Section 2 establishes a simple model of socially rewarded environmental behaviour containing the elements just mentioned. Section 3 studies the effects of changes in environmental policy on this behaviour. In particular, I am interested in the crowding-out issue. In Section 4, optimal environmental policies are analysed and the question is raised whether flexible instruments such as taxes are preferable to command and control. In Section 5, I look at results of majority voting. How do environmental policies chosen by diverse groups in society differ? Section 6 contains some final thoughts.

Before I start, a remark about the use of the term "voluntary abatement" needs to be made. I will use the notion of voluntary abatement to characterise that part of abatement effort which goes beyond the level required (or strived at) by environmental regulation. For instance imagine an abatement effort $A$ enforced via an emission tax or another environmental-policy instrument. If $a$ is an observed individual abatement level that eceeds $A$, I call $a-A$ the voluntary abatement. Strictly speaking, this abatement is not purely voluntary. People acting "voluntarily" receive social rewards. Conceptually, social rewards and sanctions are not much different from the pecuniary incentives and disincentives created by market instruments of environmental policy or from legal sanctions. Nevertheless I will use the term "voluntary abatement" to characterise the abatement going beyond what is required by the law. After this semantic remark, the analysis can begin.

self image, which may indeed be socially influenced and, thus, may depend on the (observable) general level of compliance. This is closely related to the issue of moral motivation discussed in Brekke/Kverndokk/Nyborg (2003). 


\section{The Model}

Consider a society consisting of a large number of individuals and let population size be one. This society consists of two types of individuals. One type responds to social rewards and the other does not. It is plausible to argue that the latter group is to a large extent composed of competitive firms, which react to monetary incentives only. A firm spending resources on activities that are socially beneficial but are not rewarded by the market will not remain competitive and will be be driven out of the market. Ethical considerations or social recognition do not play a role. See, e.g., Siebert $(1992,130)$ for this argument. ${ }^{4}$ Ethical behaviour and voluntary contribution to public goods are feasible only for the non-competitive part of the economy and for agents involved in non-market activities, in particular private households. For the sake of brevity the two types will be referred to as "type $S$ " for the people responding to social interactions and "type $\mathrm{C}$ " for the competitive part of the economy, which reacts to economic incentives and command-and-control only. Assume that S- and Ctype individuals are identical in all other respects and that shares of the two groups in the population, $z$ and $(1-z)$, are constant. ${ }^{5}$

If no abatement is undertaken, each individual discharges $E$ into the environment. Let $A$ be the abatement level required by the environmental regulation. Individuals not responding to social norms discharge $E$ - $A$. The other individuals abate $a \geq A$ and $a-A$ is is called voluntary abatement. Emission abatement is costly, the cost function $c(A)$ being increasing and strictly convex: $c^{\prime}()>$.0 and $c^{\prime \prime}()>$.0 . Let $T$ be the emission tax rate paid by type-C individuals. Then four kinds of environmental regulation can be distinguished:

- $T=A=0$ : $\quad$ laissez faire, i.e. no environmental regulation,

4 Non-profit motives can survive, however, if firms enjoy market power and appropriate rents that can be spent on socially rewarded activities such as environmentally friendly production or sponsorship of culture, science, and sports. In a changing world in which branded products become increasingly important at the expense of standardised commodities and in which perfect competition is being replaced by non-competitive market structures, the share of firms that are subject to social control may actually be increasing

5 Models in which the population shares are endogenous have been analysed by Schelling (1978), Naylor (1990), Myles/Naylor (1996), Lai/Yang/Chang (2003) and Nyborg/Rege (2003). The main difference between their models and the present one is that they look at a dichotomous decision whether or not to contribute to a public good and that the shares of contributors and non-contributors are variable. This paper in contrast assumes that the shares of the two types of individuals in society are given but that the degree of contribution may change. 
- $A>0, T=0$ : $\quad$ command and control,

- $A>0, T=c^{\prime}(A)$ emission taxes, tradable permits, or abatement subsidies,

- $A>0, T<c^{\prime}(A)$ a combination of command and control with small effluent fees or abatement subsidies which are not binding.

The fourth category is rather uncommon and this type of environmental regulation is introduced for analytical reasons, which will become obvious later. To simplify notation in the following parts of the paper, I introduce a dummy variable $D$ such that:

$$
D=\left\{\begin{array}{lll}
0 & \text { if } & T<c^{\prime}(A) \\
1 & \text { if } & T=c^{\prime}(A)
\end{array}\right.
$$

Thus, $D=1$ denotes the case of market instruments in environmental policy and $D=0$ stands for command and control where effluent charges may exist, but are merely symbolic and do not influence the behaviour of the $\mathrm{C}$-sector of the economy.

Voluntary emission reductions are socially rewarded. In return to her effort to reduce emissions below the level required by the environmental regulation, the individual earns a social reward, which generates some positive utility. The social reward accruing to a single individual depends positively on her own abatement effort and negatively on the abatement efforts of the rest of society. The idea behind this is that social rewards - and social norms- are related to what other people do. The more abatement other people undertake, the more difficult is it for an individual to earn social recognition. Define

$$
a^{*}=z a+(1-z) A
$$

as the average abatement level. Then the social-rewards function is defined as $s\left(a, a^{*}\right)$ with $s_{a}\left(a, a^{*}\right)>0, s_{a *}\left(a, a^{*}\right)<0$, subscripts denoting partial derivatives. $s_{a}\left(a, a^{*}\right)>0$ indicates that more abatement effort is always socially rewarded. I neglect the possibility that too much effort might be considered to be foolish and might possibly not be acknowledged. $s_{a^{*}}\left(a, a^{*}\right)<0$ represents the fact that a high level of individual abatement is less admirable if everyone abates a lot than if the average abatement is low. Note that an externality is involved here. By increasing her own abatement effort, an individual contributes to an increase in the average abatement level and thus to a reduction in social rewards. Social norms are driven by individual behaviour and each individual engaging in effort to fulfill the social norm drives the standard up. As regards second derivatives of $s\left(a, a^{*}\right)$, assume that $s$ is concave in $a: s_{a a} \leq 0$, arguments of the function omitted for convenience. Moreover, as a normalisation I use $s\left(a^{*}, a^{*}\right)=0$, i.e. average behaviour does not induce positive social rewards 
irrespective of the amount of abatement. As regards the cross derivative, one might conjecture that the marginal social reward of an individual is decreasing in the abatement acitivities of the rest of society, but it is easy to construct sensible functions such that the reverse is true. I give two examples:

$$
\begin{aligned}
& s=\frac{a^{1-\eta}-a^{* 1-\eta}}{1-\eta}, \\
& s=\frac{a^{1-\varepsilon} a^{\varepsilon-1}-1}{1-\varepsilon}
\end{aligned}
$$

with $\eta \geq 0$ and $\varepsilon \geq 0$. For $\eta=0$ and $\varepsilon=0$, these formulae simplify to specifications where social recognition is set equal to absolute and relative deviations of the individual from the avarage, respectively. With specification (3a), $s_{a a^{*}}$ is always zero. With (3b), $s_{a a^{*}}<0$ if $\varepsilon<1$ and $s_{a a^{*}}>0$ if $\varepsilon>1$. In the first case, increased abatement by others reduces the productivity of own abatement in the generation of social rewards and thus discourages abatement. In the second case, more abatement by others encourages more abatement by the individual under consideration. Thus, the sign of $s_{a a^{*}}$ is indeterminate. Holländer (1990) starts from a linear specification of the social-rewards function and employs arguments of social consistency based on individual willingness to contribute to social rewards to endogenously determine parameters of the function. This supply of social rewards depends on the marginal rate of substitution between public and private goods. Using this to parameterise the linear social-rewards function, Holländer ends up with a function that is in fact nonlinear. In contrast, I use a more general social-rewards function to start with but do not raise the question of supply of social rewards.

Indvidual well-being depends on abatement cost, tax payments, utility from social rewards, and on the disutility from pollution. The utility generated by social rewards is $u(s), u($.$) having the normal properties: positive and decreasing marginal utility,$ $u^{\prime}>0, u^{\prime \prime}<0$. Moreover, environmental pollution, $P$, is the the sum of all individual emissions and it is taken as given by each individual.

$$
P=E-a^{*}=E-z a-(1-z) A,
$$

where total emissions equal average emissions since the population size has been normalised to unity. Let environmental damage be a strictly convex function $d(P)$ of pollution, i.e. $d^{\prime}($. $)>0$ and $d^{\prime \prime}()>$.0 . The total utility of a socially responsive individual then is

$$
w^{S}=-c(a)+u\left(s\left(a, a^{*}\right)\right)-d\left(E-a^{*}\right)-t \cdot(E-a)
$$


where $t$ is the emission tax rate paid by type-S individuals. It should be noted that an abatement subsidy instead of an emission tax would not change the results. Just interpret $+t a$ as the abatement subsidy and $-t E$ as a lump-sum tax, which is neutral. Thus all results to be derived in the remainder of the paper carry over from emission taxes to abatement subsidies.

For most of the remainder of the paper, I assume that both groups of society are subject to the same environmental regulation.

Assumption 1: $t=T$.

Only in Section 4.3 will this assumption be relaxed and I will consider the possibility of discriminating environmental regulation. The motivation behind Assumption 1 is that is in practice difficult, if not possible, to distinguish the two types. If they could be distinguished and if differentiated environmental policies could be applied, it would be questionable whether social rewards would still depend on the average level of abatement in society or rather on the group-specific abatement requirement applicable to type-S individuals.

\section{The Effect of Environmental Policy on Voluntary Abatement and on the Environment}

\subsection{Optimal Voluntary Abatement}

The optimal abatement level a representative type-S individual is determined by differentiation of (5) subject to $a \geq A$ with respect to $a$. The first-order condition is

$$
-c^{\prime}(a)+u^{\prime}(s) s_{a}\left(a, a^{*}\right)+t \leq 0,
$$

where the left-hand side is negative if the constraint is binding. From (6), the following result can be inferred.

Proposition 1. In the case of market instruments of environmental policy $(D=1)$, there will always be voluntary abatement: $a>A$. In the case of pure command and control without any taxes $(t=T=0), a>A$ only if $u^{\prime}(0) s_{a}(A, A)>c^{\prime}(A)$.

Proof. Assume $a=A$. Then condition (6) reads $u^{\prime}(0) s_{a}(A, A)+t \leq c^{\prime}(A)$. If $D=1, c^{\prime}(A)=T=t$ and condition (6) is violated. Thus, $a=A$ cannot be true. If $t=0$, condition (6) turns out to be $u^{\prime}(0) s_{a}(A, A) \leq c^{\prime}(A)$. If this condition is violated, $a=A$ must be wrong. Then, $a>A$. 
The intuition behind this proposition is rather straightforward. In the case of emission taxes, all individuals try to avoid the emission tax by abating at least $A$ irrespective of whether they respond to social recognition. The demand for social recognition generates incentives to increase abatement beyond this level. Under command and control, there is no cost of not abating that can be avoided. If the marginal utility from social recognition is less than the marginal abatement cost, even socially responsive individuals will not abate more than the required minimum. This is closely related to a point made by Diekmann and Preisendörfer (2003). They distinguish between lowcost and high-cost situations. If environmentally concerned individuals face low (marginal) costs of environmentally friendly behaviour, they will behave in an environmentally friendly way. If the costs are high, they will behave like their environmentally unconcerned fellow citizens and choose just the minimum action required. Proposition 1 shows that this argument carries over from intrinsic motivation to the extrinsic motivation to earn social recognition. If marginal abatement costs are high, socially responsive people neglect social rewards and just do the required minimum.

In the remainder of the paper, I wish to confine myself to situations with voluntary abatement and social rewards and therefore I assume that the marginal benefits from social rewards always at least outweigh the marginal cost of obtaining them:

Assumption 2: $u^{\prime}(0) s_{a}(A, A)>c^{\prime}(A)$.

With boundary solutions ruled out, the optimality condition is

$$
c^{\prime}(a)-u^{\prime}(s) s_{a}\left(a, a^{*}\right)=t .
$$

In the case of an emission tax, the marginal cost of abatement equals the tax rate plus the marginal utility of social rewards. Otherwise, the marginal cost equals the marginal utility. The second-order condition is satisfied.

\subsection{Environmental Policy and Voluntary Abatement}

If we want to identify the impact of environmental policy measures on voluntary abatement, two variables are of interest. The first one is the strictness of environmental regulation measured by $A$. The second one is the type of environmental regulation: what is the consequence of a move from command and control to marketoriented environmental policies? This will be analysed by varying the tax rate $t$ such that the behaviour of the $\mathrm{S}$ sector is not affected, i.e. we look at an effluent charge 
which is so small that it does not affect abatement by the $\mathrm{C}$ sector of the economy: $t=T<c^{\prime}(A)$.

Total differentiation of equation (6') gives the desired results. It has to be taken into account now that in equilibrium $a^{*}=z a+(1-z) A$. Moreover, in the case of a market approach in environmental policy, the change in the tax rate accompanying the change in abatement $A$ is $d T=c^{\prime \prime}(A) d A$. Thus,

$$
\frac{d a}{d t}=\frac{1}{c^{\prime \prime}(a)-u^{\prime \prime} s_{a}\left(s_{a}+z s_{a^{*}}\right)-u^{\prime}\left(s_{a a}+z s_{a a^{*}}\right)} \quad \text { if } t=T<c^{\prime}(A)
$$

and

$$
\frac{d a}{d A}=\frac{D c^{\prime \prime}(A)+(1-z)\left(u^{\prime \prime} s_{a} s_{a^{*}}+u^{\prime} s_{a a^{*}}\right)}{c^{\prime \prime}(a)-u^{\prime \prime} s_{a}\left(s_{a}+z s_{a^{*}}\right)-u^{\prime}\left(s_{a a}+z s_{a a^{*}}\right)} \quad \text { if } t=T=c^{\prime}(A) .
$$

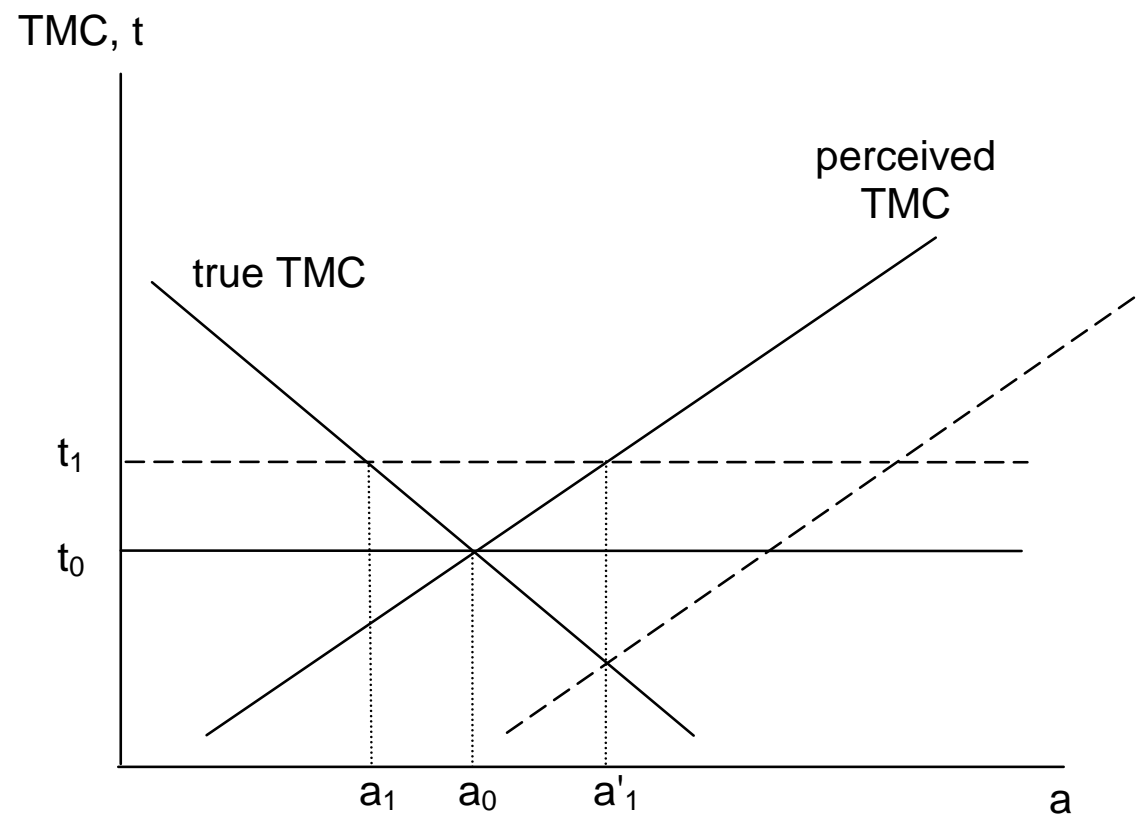

Figure 1: Effects of an increase in the emission tax

The denominators on the right-hand sides of equations (7) and (8) are identical and are likely to be positive. There are two terms that may exhibit the "wrong" negative signs: $-z u^{\prime} s_{a a^{*}}$ and $-z u^{\prime \prime} s_{a} s_{a^{*}}$. To illustrate what a negative denominator means, let us look at a change in the tax rate like the one in equation (7). If the tax rate is increased, an individual takes $a^{*}$ as given and increases abatement since total marginal cost (TMC), i.e. marginal abatement cost minus marginal utility, seems to be increasing. In Figure 1, this is depicted by a positively sloped "perceived TMC" 
curve. Ex post, however, since other individuals behave in the same way, $a^{*}$ does change and this is taken into account in the denominator of (7). A negative denominator means that the "true TMC" curve, originating if all type-S individuals do the same thing, is negatively sloped and the equilibrium is at an abatement level $a_{1}$. The incentives faced by the individual under consideration, however, make her choose $a_{1}^{\prime}$, which is too large. All individuls do this and, thus, the true TMC is revealed and the perceived TMC curve is shifted downwards. This is an incentive to further raise the abatement level and it is obvious that the new equilibrium is unstable and that $a_{1}$ will never be reached. Let us, therefore, assume that the denominator is positive. In particular, we make

Assumption 3: $s_{a}+z s_{a^{*}} \geq 0$ and $s_{a a}+z s_{a a^{*}} \leq 0$.

Remark. The first part of Assumption 3 is satisfied for the additive specification, (3a), if $\eta \leq 1$ and for the multiplicative specification, (3b), for all values of $\varepsilon$. The second condition is satisfied for both specifications for all admissible parameter values. Table 1 contains the detailed results.

\begin{tabular}{|l|c|c|}
\cline { 2 - 3 } & $s=\frac{a^{1-\eta}-a^{* 1-\eta}}{1-\eta} \quad(3 \mathrm{a})$ & $s=\frac{a^{1-\varepsilon} a^{*^{\varepsilon-1}}-1}{1-\varepsilon}$ \\
\hline$s_{a}+z s_{a^{*}}=$ & $\left(1-z\left(z+(1-z) \frac{A}{a}\right)^{-\eta}\right) a^{-\eta}$ & $\frac{(1-z) A}{a^{\varepsilon} a^{2-\varepsilon}}$ \\
\hline$s_{a a}+z s_{a a^{*}}=$ & $-\eta a^{-1-\eta}$ & $-\frac{a+(1-z) \varepsilon A}{a^{\varepsilon+1} a^{2-\varepsilon}}$ \\
\hline
\end{tabular}

Table 1: Assumption 3 in Cases of Specifications (3a) and (3b)

With this assumption, the following result follows from condition (7):

Proposition 2. A marginal increase in the emission tax that has no effect on type-C individuals raises the abatement by type-S individuals.

Proof. With assumption 3, the denominator in (7) is unambiguously positive. 
The underlying intuition is that the tax increase raises the opportunity cost of discharging pollutants. There is no crowding-out effect in the sense that socially valuable behaviour is devalued if a price is attached to it. It may be true that regulations introducing pecuniary incentives for activities that have been subject to nonpecuniary rewards before, destroy moral and social values, but not in this model. ${ }^{6}$

From the other equation, (8), the following result follows immediately:

Proposition 3. A stricter environmental policy has ambiguous effects on abatement by type-S individuals. Under emission taxes, the same increase in abatement requirements for type $\mathrm{C}$ induces more abatement by type $\mathrm{S}$ than under command and control.

Proof. If Assumption 3 holds, the denominator in (8) is unambiguously positive. The numerator contains two positive terms, $D c^{\prime \prime}(A)$ and $(1-z) u^{\prime \prime} s_{a} s_{a^{*}}$, and one that is possibly negative, $(1-z) u^{\prime} s_{a a^{*}}$. Thus, the sign of the numerator is ambiguous. Since, $c^{\prime \prime}(A)>0$, a change from $D=0$ to $D=1$ increases $d a / d A$.

The three effects in the numerator can be explained as follows. $c(A)$ is the increase in the emission tax necessary to induce more abatement by type $C$. To type $S$, this change in the tax raises the real cost of polluting and induces more abatement, too. $(1-z) u^{\prime \prime} s_{a} s_{a^{*}}$ states that an increase in $A$ reduces average abatement, $a^{*}$, which reduces the marginal social reward from abatement and this in turn raises the marginal utility from social rewards. Thus, there is an additional incentive to abate. In contrast, $(1-z) u^{\prime} s_{a a^{*}}$ represents a discouragement effect if $s_{a a^{*}}<0$. Then increased abatement by others reduces the marginal productivity of own abatement in generating social rewards. The result that taxes generate more abatement by type-S individuals is explained by the fact that a tax increases the marginal cost of discharging pollutants. In particular,

$$
\left.\frac{d a}{d A}\right|_{\operatorname{tax}}=\left.\frac{d a}{d A}\right|_{\mathrm{CAC}}+D c^{\prime \prime}(A) \frac{d a}{d t},
$$

where $d a / d t$ is given by equation (7) and CAC stands for "command and control".

6 Experimental evidence showing that this kind of crowding-out is relevant in some real-world situations is provided by Gneezy/Rustichini (2000a,b). Lai/Yang/Chang (2003) in their theoretical model assume that an individual's propensity to react to social norms depends on the tax rate. Albeit a bit ad hoc, such an assumption can generate a large variety of behaviours. The approach suggested by Bénabou/Tirole (2006), who argue that individuals reacting to pecuniary incentives face the problem of being regarded by others as greedy, however, seems to be more satisfactory. 
The next question to be addressed here is that of crowding out of voluntary abatement by decreed abatement. Define voluntary abatement as $a-A$. Then

$$
\frac{d(a-A)}{d A}=\frac{d a}{d A}-1=\frac{D c^{\prime \prime}(A)-c^{\prime \prime}(a)+u^{\prime \prime} s_{a}\left(s_{a}+s_{a^{*}}\right)+u^{\prime}\left(s_{a a}+s_{a a^{*}}\right)}{c^{\prime \prime}(a)-u^{\prime \prime} s_{a}\left(s_{a}+z s_{a^{*}}\right)-u^{\prime}\left(s_{a a}+z s_{a a^{*}}\right)}
$$

Inspection of (10) gives

Proposition 4. The impact of environmental regulation on voluntary emission reduction is ambiguous.

Proof. There are several positive and negative terms in the numerator and it is not clear which terms dominate.

Crowding out of socially rewarded behaviour is likely. Voluntary abatement may be increased if

- $c^{\prime \prime}(A)$ is very large compared to $c^{\prime \prime}(a)$. In this case, the tax increase necessary to induce the increase in $A$ is large whereas the increase in marginal cost of additional abatement by type-S persons is small.

- $s_{a^{*}}$ is large in absolute value. Then abatement by others reduces social rewards substantially and this raises the marginal utility from social rewards.

- $s_{a a^{*}}$ is positive and large. Then, increased abatement efforts by others raise the social recognition gained by own abatement efforts of individuals of type $\mathrm{S}$.

\subsection{Environmental Regulation and Environmental Quality}

Let us now consider the effects of environmental regulation on pollution. Since type$S$ individuals may be induced by stricter environmental standards to increase their emissions, it is by no means clear that such a stricter environmental regulation is good for the environment. From equations (2) and (8), we have

$$
\frac{d a^{*}}{d A}=1-z+z \frac{d a}{d A}=\frac{z D c^{\prime \prime}(A)+(1-z) c^{\prime \prime}(a)-(1-z)\left(u^{\prime \prime} s_{a}^{2}+u^{\prime} s_{a a}\right)}{c^{\prime \prime}(a)-u^{\prime \prime} s_{a}\left(s_{a}+z s_{a^{*}}\right)-u^{\prime}\left(s_{a a}+z s_{a a^{*}}\right)}
$$

and this implies:

Proposition 5. Stricter environmental regulation reduces environmental pollution.

Proof. Assumption 3 guarantees a positive denominator in (11). All terms in the numerator are unambiguously positive. 
Although type-S individuals may be induced to increase their emissions, the overall effect is an emission reduction. The reason is that the effect that might induce type-S persons to raise their emissions depends negatively on the share of type-S individuals, $z$. See equation (8). Thus, the stronger the effect, the smaller is the number of exhibiting this behaviour. Of course, if it were possible that the share of socially responsive individuals, $z$, could change as a consequence of tighter environmental standards like in Lai/Yang/Chang (2003), a worsening of environmental quality would become feasible.

\section{Welfare Effects and Optimal Environmental Policies}

\subsection{Welfare and the Pigouvian Tax}

In a society where environmentally responsible behaviour is driven by social norms, there is more than one externality. Not only does the individual neglect her impact on environmental pollution; she also does not consider that her own abatement activities have an impact on the social rewards that other people receive. It is, therefore, unlikely that the standard policy implication of environmental economics, the Pigouvian tax rule, applies here. The Pigouvian tax equalises marginal damage and marginal cost of abatement for the type-C part of society:

$$
T=c^{\prime}(A)=d^{\prime}\left(E-a^{*}\right)
$$

All individuals being treated equally, social welfare, $W$, is the unweighted sum of all individual utilities. It is assumed that tax revenues are re-injected into the economy in a lump-sum fashion. Thus, the tax payment and the public expenditure cancel out when social welfare is calculated.

$$
W=-z c(a)-(1-z) c(A)+z u\left(s\left(a, a^{*}\right)\right)-d\left(E-a^{*}\right)
$$

$W$ is not necessarily concave in the policy instrument, $A$. For instance, $d a / d A$ (equation (8)) contains several second derivatives implying that $d W / d A$ contains these derivatives as well and that $d^{2} W / d A^{2}$ then contains third derivatives. Thus, I make the following assumption such that the second-order condition is satisfied.

Assumption 3: $d^{2} W / d A^{2}<0$.

Is the Pigouvian tax optimal in this model and, if not, is it is too large or too small? Differentiation of (12) with respect to $A$ yields:

$$
\frac{d W}{d A}=\left(1-z+z \frac{d a}{d A}\right)\left(d^{\prime}+z u^{\prime} s_{a^{*}}\right)-(1-z) c^{\prime}(A)+z\left(u^{\prime} s_{a}-c^{\prime}(a)\right) \frac{d a}{d A}
$$


with $d a / d A$ being determined by equation (8). Using the $\mathrm{S}$ sector's first-order condition, equation $\left(6^{\prime}\right)$, yields

$$
\frac{d W}{d A}=\left(1-z+z \frac{d a}{d A}\right)\left(d^{\prime}+z u^{\prime} s_{a^{*}}\right)-(1-z) c^{\prime}(A)-z t \frac{d a}{d A},
$$

Inserting the Pigouvian tax rule, (12), into (14) and using $T=t=c^{\prime}(A)$, yields

$$
\left.\frac{d W}{d A}\right|_{d^{\prime}=c^{\prime}(A)}=\left(1-z+z \frac{d a}{d A}\right) z u^{\prime} s_{a^{*}}
$$

and this shows that a Pigouvian environmental tax is not optimal since it does not internalise the effect of changing social rewards on welfare.

Proposition 6. Pigouvian taxation as defined by (13) is too strict.

Proof. The term in brackets on the right-hand side is $d a * / d A$, which is positive (Proposition 5), and $s_{a^{*}}$ is negative. Thus, an increase in C-sector abatement $A$, has a negative effect on welfare and this implies that the welfare maximum is located at a lower abatement level.

The intuition behind Proposition 6 is that tighter environmental standards reduce social rewards. This implies that environmental regulation should be relaxed compared to a situation where only the environment, but not social norms, matter.

\subsection{Optimal Environmental Regulation with One Instrument}

Given that the Pigouvian tax does not satisfy the first-order condition of optimality, a better environmental policy is sought. Setting $d W / d A=0$ in equation (14) gives

$$
c^{\prime}(A)=\left(1+\frac{z}{1-z} \frac{d a}{d A}\right)\left(d^{\prime}+z u^{\prime} s_{a^{*}}\right)-\frac{z}{1-z} t \frac{d a}{d A}
$$

If the policy instrument is a tax, $t=T=c^{\prime}(A)$ and it follows that

$$
\left.T=c^{\prime}(A)=d^{\prime}+z u^{\prime} s_{a^{*}} \quad \text { (for } D=1\right) .
$$

In the case of command and control with $t=T=0$,

$$
c^{\prime}(A)=\left(1+\frac{z}{1-z} \frac{d a}{d A}\right)\left(d^{\prime}+z u^{\prime} s_{a^{*}}\right) \quad(\text { for } t=T=D=0) .
$$

From (17a) and (17b), one can conclude

Proposition 7. Assume a non-discriminating environmental policy. If the instrument is a tax, the optimal tax rate is less than marginal environmental damage. In the case of pure command and control, the shadow 
price of emissions is positive and may be larger or less than the environmental damage and larger or less than the optimal tax rate .

Proof. In equation (17a), the second term on the right-hand side is unambiguously negative. In equation (17b), the first term in brackets is positive due to condition (11). Using (11) and $D=0,(17 \mathrm{~b})$ can be rewritten:

$$
c^{\prime}(A)=\frac{c^{\prime \prime}(a)-\left(u^{\prime \prime} s_{a}^{2}+u^{\prime} s_{a a}\right)}{c^{\prime \prime}(a)-u^{\prime \prime} s_{a}\left(s_{a}+z s_{a^{*}}\right)-u^{\prime}\left(s_{a a}+z s_{a a^{*}}\right)}\left(d^{\prime}+z u^{\prime} s_{a^{*}}\right)
$$

If $s_{a a^{*}} \geq 0$, the fraction on the left-hand side is larger than 1 and the implicit price of emisions is larger than the tax rate defined in (17a) and may be larger than the environmental damage. If $s_{a a^{*}}<0$, the fraction can be less than 1 and the shadow price can be less than the tax rate.

The difference between environmental taxation and the command-and-control approch is that command and control does not provide incentives that influence the behaviour of type-S individuals directly. Thus, the levels of optimal environmental regulation depend on the instruments used. One may now ask which approach to environmental policy is better under the given circumstances. An answer will be given in the next section, where two policy instruments are considered.

\subsection{Optimal Environmental Regulation with Two Instruments}

Given that there are two externalities in this model, one being related to the environmental problem and the other one to social norms, two policy instruments might be better than one. There are two possibilities of dealing with this. On the one hand, one could discriminate between type-S and type-C individuals and implement groupspecific rules. Assume for a moment that this is possible. On the other hand, one can design a single environmental policy consisting of two instruments that affect the two groups in different ways. In this case, we would look at the combination of a tight emission standard with a low emission tax, such that the emission tax is of mere symbolic nature to the $\mathrm{C}$ sector, but affects the behaviour of type- $\mathrm{C}$ individuals.

In what follows, I determine an optimal tax rate for type-S individuals that can be combined with an optimal (command-and-control or tax) regulation of the $\mathrm{C}$ sector. The problem is to maximise social welfare, (13), with respect to the tax rate $t$. Thus, the first-order condition is

$$
\frac{d W}{d t}=z\left(d^{\prime}-c^{\prime}(a)+u^{\prime}\left(s_{a}+z s_{a^{*}}\right)\right) \frac{d a}{d t}=0
$$


with $d a / d t$ being determined by equation (7). Using the $\mathrm{S}$ sector's first-order condition, equation (6'), yields

$$
t=d^{\prime}+z u^{\prime} s_{a^{*}} .
$$

This is the same condition as that for the taxation of the $\mathrm{C}$ sector, equation (17a). From this and from using (18) in (16), we have

Proposition 8. If two policy instruments can be chosen, the optimal policy is characterised by

$$
t=T=d^{\prime}+z u^{\prime} s_{a^{*}}
$$

and a discrimination between type- $\mathrm{C}$ and type- $\mathrm{S}$ individuals is not required.

Proof. The optimal regulation of the $\mathrm{C}$ sector for any given S-specific tax rate $t$ is determined by (16). Using (18) in (16) implies $c^{\prime}(A)=d^{\prime}+z u^{\prime} s_{a^{*}}$ This can be implemented by the tax rate derived in (18) because $T=c^{\prime}(A)$.

In other words, the two policy instruments collapse into one. There is no reason to discriminate between the $\mathrm{S}$ and the $\mathrm{C}$ sectors of the economy. The rationale is that both sectors generate the same externalities: an environmental externality and a second externality via the impact of abatement on the social rewards accruing to the type-S people. In both sectors, $\mathrm{C}$ and $\mathrm{S}$, the mechanism generating this latter externality is the same. There is increase in the average abatement effort, which is the bechmark against which individual effort is measured. Matters would be different if there were a direct negative effect of regulation of the $\mathrm{C}$ sector on social rewards accruing to the $\mathrm{S}$ sector. With such a negative externality of $\mathrm{C}$ abatement, the regulation of the $\mathrm{C}$ sector should be relaxed compared to that of the $\mathrm{S}$ sector.

From the way in which Proposition 8 has been derived, one can draw an additional conclusion.

Proposition 9. An optimal emission tax is better than optimal command and control.

Proof. For any tax rate (including zero) for the S sector, (16) determines the optimal regulation of the $\mathrm{C}$ sector. Gradually introducing a tax for the $\mathrm{S}$ sector, we ultimately arrive at an optimum and the optimal tax rate equals the tax rate that would induce the $\mathrm{C}$ sector to choose the same abatement level as under command and control. 
This is a notable deviation from the standard result of environmental economics in a competitive world, where flexible instruments and command and control are equivalent. In the present model, the impact of command and control on the S sector would only be indirect, via the change in social rewards induced by the change in general abatement requirements. An instrument that directly influences the behaviour of type-S individuals is a tax. Since the two sectors generate the same externalities, both environmentally and via social norms, the optimal tax rate is the same.

\section{Majority Voting}

The previous section has assumed a benevolent utilitarian dictator maximising a social-welfare function in which all individuals have equal weights. We now look at majority voting. Either $z<1 / 2$ and type-C individuals dominate the decision about environmental policy or $z>1 / 2$ and type-S individuals decide. Assume that only environmental policy is on the agenda and that concerns about the distribution of the emission tax revenue are not considered. Otherwise, the dominating group would have a tax-revenue motive and would try to exploit the other group via the tax system. In the economic analysis, marginal-tax-revenue rules and Laffer-curve arguments would turn up. To rule out these effects, assume that tax revenues are recycled as lump-sum transfers to the group paying the taxes. Moreover, I assume that there is only one policy instrument, equally applied to both groups in society.

Let us first consider majority voting by type-C individuals. Their objective function is

$$
W^{C}=-c(A)-d\left(E-a^{*}\right)
$$

and the first-order condition is

$$
c^{\prime}(A)=\left((1-z)+z \frac{d a}{d A}\right) d^{\prime}
$$

From (20), we have

Proposition 10. The optimal tax from the point of view of the $\mathrm{C}$ sector is larger (less) than the Pigouvian tax if if tighter standards lead to more (less) voluntary abatement of the S sector.

Proof. Note that more (less) voluntary abatement is equivalent to $d a / d A>(<) 1$. Then compare (20) to the Pigouvian tax rule, $c^{\prime}(A)=d^{\prime}$. 
It is not surprising that the $\mathrm{C}$ sector does not consider social-norms externalities because it is not affected by them. A positive impact of environmental regulation on voluntary abatement of the $\mathrm{S}$ sector strengthens the environmental efficiency of environmental regulation. If the marginal damage that can be avoided by an increase in abatement is large, then the optimal abatement effort is large.

Finally the issue of instrument choice shall be discussed. Does the $\mathrm{C}$ sector prefer taxes or command and control? The impact of a move from command and control towards taxes is

$$
\frac{W^{C}}{d t}=z d^{\prime} \frac{d a}{d t}>0
$$

and this directly implies

Proposition 11. The $\mathrm{C}$ sector prefers taxes to command and control.

The underlying reason is that taxes induce the $\mathrm{S}$ sector to do more for the environment without any cost to be borne by the $\mathrm{C}$ sector.

Let us now consider majority voting by type-S individuals. The objective function is

$$
W^{S}=-c(a)+u\left(s\left(a, a^{*}\right)\right)-d\left(E-a^{*}\right)
$$

and the first-order condition turns out to be

$$
\left(c^{\prime}(a)-u^{\prime} s_{a}\right) \frac{d a}{d A}=\left(d^{\prime}+u^{\prime} s_{a^{*}}\right) \frac{d a^{*}}{d A},
$$

where $d a / d A$ and $d a * / d A$ are determined by equations (8) and (11), respectively. Using the first-order condition, $\left(6^{\prime}\right)$ to substitute for $c^{\prime}(a)-u^{\prime} s_{a}$, we have,

$$
t \frac{d a}{d A}=\left(d^{\prime}+u^{\prime} s_{a^{*}}\right) \frac{d a^{*}}{d A}
$$

where $t=c^{\prime}(A)$ in the case of emission taxes and $t=0$ under command and control. Thus,

$$
\begin{array}{ll}
d^{\prime}+u^{\prime} s_{a^{*}}=0 & \text { under command and control, } \\
d^{\prime}+u^{\prime} s_{a^{*}}=\frac{d a / d A}{d a^{*} / d A} c^{\prime}(A) & \text { under emission taxes. }
\end{array}
$$

Interestingly, the optimal environmental regulation from the point of view of the $S$ sector is independent of this sector's marginal abatement cost (although second derivatives are contained in $d a / d A$ and $d a * / d A$ ). The optimal command-and-control regulation should be designed such that the two externalities generated by the $S$ 
sector just cancel out at the margin. In the case of an emission tax, a wedge arises since the tax is a real cost to the individual agent, whereas it is not for the voter, who knows the rule of reimbursement. Thus, the intuition is that command and control is better than taxes and the following considerations confirm this conjecture. Differentiation of $W^{S}$ with respect to $t$, noting that $A$ is constant for small tax rates and that, therefore, $d a * / d t=z d a / d t$ yields

$$
\frac{d W^{S}}{d t}=\left(z\left(d^{\prime}+u^{\prime} s_{a^{*}}\right)+u^{\prime} s_{a}-c^{\prime}(a)\right) \frac{d a}{d t} .
$$

Using (6') and (23), we have

$$
\frac{d W^{S}}{d t}=\left(z \frac{d a / d A}{d a^{*} / d A}-1\right) t \frac{d a}{d t}
$$

This implies

Proposition 12. The $\mathrm{C}$ sector prefers command and control to taxes. The optimal tax rate is zero.

Proof. Rewrite the term in brackets on the left-hand side of (25) such that $z \frac{d a / d A}{d a^{*} / d A}-1=\frac{-(1-z)}{d a^{*} / d A}$. Thus, if an existing tax rate is positive (negative), it welfare-improving to reduce (increase) it.

The underlying rationale is that an optimal regulation just equates the two externalities (equation (24a)) and that taxation induces a wedge between the decision rules for the individual and for the sector as a whole.

This section has shown, that the $\mathrm{C}$ and the $\mathrm{S}$ sectors have different perceptions on what constitutes a good environmental policy. Type-C individuals like taxes whereas type-S individuals prefer command and control. In both cases the reason is that taxes shift the burden of cleaning up the environment from the $C$ sector to the $S$ sector. It should be noted that this results has been obtained under the assumption that tax revenues are re-distributed such that each tax payer exactly gets back what she has paid, i.e. considerations about the redistribution of tax revenues have been excluded by assumption.

\section{Final Remarks}

This paper has shown that social norms and environmental regulation interact in a way that gives rise to interesting policy implications. In particular, I find that 
command and control and flexible instruments generate different effects even though individuals are price takers in this model. Optimal environmental policies differ from the standard Pigouvian policies since social norms generate additional externalities that an optimal policy should take into account. In this context it is shown that taxes are better than standards. However, when it comes to political decision making, status-responsive individuals would vote against such a policy and in favour of command and control.

Unlike in some other models, the introduction of taxes does not crowd out voluntary abatement. On the contrary, it provides incentives to increase abatement. There exists the theoretical possibility, however, that the converse happens, but the resulting equilibrium is unstable and this has been excluded by Assumption 2.

Some caveats are indicated. Firstly, I have treated the supply of social rewards (or social sanctions) as exogenous to the model. In other models this supply is related to the share of people exhibiting prosocial behaviour. In the present model, this share is constant, which makes sense if we think of a $\mathrm{C}$ sector subject to competitive pressure and an $\mathrm{S}$ sector that responds to social rewards. Secondly, besides the unstable-equilibrium case, there is nothing in this model generating the effect that the mere introduction of a price crowds out social norms. As Gneezy/Rustichini (2000a,b) have shown, however, this crwoding out can be relevant in some realworld situations. The approach taken by Lai/Yang/Chang (2003), who assume that the propensity to react to social sanctions or rewards is related to the price incentive, is not particularly satisfactory. The more recent paper by Bénabou/Tirole (2006) shows how this can be modelled more convincingly in a signalling framework and I expect future research in the field to go into this direction. I conjecture that my result of the superiority of taxes over command and control will be challenged by such models, but other results of this paper, in particular those related to social-status externalities and imperfection of Pigouvian taxes will carry over to more complex models. 


\section{References}

Bénabou, R., J. Tirole, 2006, Incentives and Prosocial Behaviour, forthcoming in American Economic Review.

Brekke, K.A., S. Kverndokk, K. Nyborg, 2003, An Economic Model of Moral Motivation, Journal of Public Economics 87, 1967-1983.

Cardenas, J.C., J. Stranlund, 2000, Local Environmental Control and Institutional Crowding-Out, World Development 28, 1719-1733.

Diekmann, A., P. Preisendörfer, 2003, Green and Greenback: The Behavioral Effects of Environmental Attitudes in Low-Cost and High-Cost Situations, Rationality and Society, 15, 441-472.

Frey, B.S., 1986, Economists Favour the Price System: Who Else Does?, Kyklos 39, 537-563.

Frey, B.S., 1992, Tertium Datur: Pricing, Regulating and Intrinsic Motivation, Kyklos 45, 161-185.

Frey, B.S., 1993, Motivation as a Limit to Pricing, Journal of Economic Psychology 14, 635-664.

Gächter, S., E. Fehr, 1999, Collective Action as a Social Exchange, Journal of Economic Behavior and Organization 39, 341-369.

Gneezy, U., A. Rustichini, 2000a, Pay Enough or Don't Pay at All, Quarterly Journal of Economics 115, 791-810.

Gneezy, U., A. Rustichini, 2000b, A Fine Is a Price, Journal of Legal Studies, 29, 118.

Hirsch, F., 1976, The Social Limits to Growth, Cambridge, MA: Harvard University Press.

Kandel, E., E. Lazear, 1992, Peer Pressure and Partnerships, Journal of Political Economy 100, 801-817.

Lai, C.-C., C.-Y. Yang, J.-J. Chang, 2003, Environmental Regulations and Social Norms, International Tax and Public Finance 10, 63-75.

Mellström, C., M. Johannesson, 2005, Crowding Out in Blood Donation: Was Titmuss Right?, Göteborg University: Unpublished manuscript.

Myles, G.D., R.A. Naylor, 1996, A Model of Tax Evasion with Group Conformity and Social Customs, European Journal of Political Economy 12, 49-66. 
Naylor, R.A., 1990, A Social Custom Model of Collective Action, European Journal of Political Economy 6, 201-216.

Nyborg, K., M. Rege, 2003, On Social Norms: The Evolution of Considerate Smoking Behavior, Journal of Economic Behavior and Oraganization, 52, 323340 .

Schelling, T.C., 1978, The Micromotives of Macrobehaviour, New York: Norton.

Siebert, H.,1992, Economics of the Environment, 3rd ed., Berlin: Springer.

Titmuss, R., 1971, The Gift Relationship, London: Allen and Unwin.

Weck-Hannemann, H., B.S. Frey, 1995, Are Incentives Instruments as Good as Economists Believe? Some New Considerations, in: L. Bovenberg, S. Cnossen, eds., Public Economics and the Environment in an Imperfect World, Boston: Kluwer, 


\title{
CESifo Working Paper Series
}

\author{
(for full list see www.cesifo-group.de)
}

1776 Richard Schmidtke, Two-Sided Markets with Pecuniary and Participation Externalities, August 2006

1777 Ben J. Heijdra and Jenny E. Ligthart, The Transitional Dynamics of Fiscal Policy in Small Open Economies, August 2006

1778 Jay Pil Choi, How Reasonable is the 'Reasonable' Royalty Rate? Damage Rules and Probabilistic Intellectual Property Rights, August 2006

1779 Ludger Woessmann, Efficiency and Equity of European Education and Training Policies, August 2006

1780 Gregory Ponthiere, Growth, Longevity and Public Policy, August 2006

1781 Laszlo Goerke, Corporate and Personal Income Tax Declarations, August 2006

1782 Florian Englmaier, Pablo Guillén, Loreto Llorente, Sander Onderstal and Rupert Sausgruber, The Chopstick Auction: A Study of the Exposure Problem in Multi-Unit Auctions, August 2006

1783 Adam S. Posen and Daniel Popov Gould, Has EMU had any Impact on the Degree of Wage Restraint?, August 2006

1784 Paolo M. Panteghini, A Simple Explanation for the Unfavorable Tax Treatment of Investment Costs, August 2006

1785 Alan J. Auerbach, Why have Corporate Tax Revenues Declined? Another Look, August 2006

1786 Hideshi Itoh and Hodaka Morita, Formal Contracts, Relational Contracts, and the Holdup Problem, August 2006

1787 Rafael Lalive and Alejandra Cattaneo, Social Interactions and Schooling Decisions, August 2006

1788 George Kapetanios, M. Hashem Pesaran and Takashi Yamagata, Panels with Nonstationary Multifactor Error Structures, August 2006

1789 Torben M. Andersen, Increasing Longevity and Social Security Reforms, August 2006

1790 John Whalley, Recent Regional Agreements: Why so many, why so much Variance in Form, why Coming so fast, and where are they Headed?, August 2006

1791 Sebastian G. Kessing and Kai A. Konrad, Time Consistency and Bureaucratic Budget Competition, August 2006 
1792 Bertil Holmlund, Qian Liu and Oskar Nordström Skans, Mind the Gap? Estimating the Effects of Postponing Higher Education, August 2006

1793 Peter Birch Sørensen, Can Capital Income Taxes Survive? And Should They?, August 2006

1794 Michael Kosfeld, Akira Okada and Arno Riedl, Institution Formation in Public Goods Games, September 2006

1795 Marcel Gérard, Reforming the Taxation of Multijurisdictional Enterprises in Europe, a Tentative Appraisal, September 2006

1796 Louis Eeckhoudt, Béatrice Rey and Harris Schlesinger, A Good Sign for Multivariate Risk Taking, September 2006

1797 Dominique M. Gross and Nicolas Schmitt, Why do Low- and High-Skill Workers Migrate? Flow Evidence from France, September 2006

1798 Dan Bernhardt, Stefan Krasa and Mattias Polborn, Political Polarization and the Electoral Effects of Media Bias, September 2006

1799 Pierre Pestieau and Motohiro Sato, Estate Taxation with Both Accidental and Planned Bequests, September 2006

1800 Øystein Foros and Hans Jarle Kind, Do Slotting Allowances Harm Retail Competition?, September 2006

1801 Tobias Lindhe and Jan Södersten, The Equity Trap, the Cost of Capital and the Firm's Growth Path, September 2006

1802 Wolfgang Buchholz, Richard Cornes and Wolfgang Peters, Existence, Uniqueness and Some Comparative Statics for Ratio- and Lindahl Equilibria: New Wine in Old Bottles, September 2006

1803 Jan Schnellenbach, Lars P. Feld and Christoph Schaltegger, The Impact of Referendums on the Centralisation of Public Goods Provision: A Political Economy Approach, September 2006

1804 David-Jan Jansen and Jakob de Haan, Does ECB Communication Help in Predicting its Interest Rate Decisions?, September 2006

1805 Jerome L. Stein, United States Current Account Deficits: A Stochastic Optimal Control Analysis, September 2006

1806 Friedrich Schneider, Shadow Economies and Corruption all over the World: What do we really Know?, September 2006

1807 Joerg Lingens and Klaus Waelde, Pareto-Improving Unemployment Policies, September 2006 
1808 Axel Dreher, Jan-Egbert Sturm and James Raymond Vreeland, Does Membership on the UN Security Council Influence IMF Decisions? Evidence from Panel Data, September 2006

1809 Prabir De, Regional Trade in Northeast Asia: Why do Trade Costs Matter?, September 2006

1810 Antonis Adam and Thomas Moutos, A Politico-Economic Analysis of Minimum Wages and Wage Subsidies, September 2006

1811 Guglielmo Maria Caporale and Christoph Hanck, Cointegration Tests of PPP: Do they also Exhibit Erratic Behaviour?, September 2006

1812 Robert S. Chirinko and Hisham Foad, Noise vs. News in Equity Returns, September 2006

1813 Oliver Huelsewig, Eric Mayer and Timo Wollmershaeuser, Bank Behavior and the Cost Channel of Monetary Transmission, September 2006

1814 Michael S. Michael, Are Migration Policies that Induce Skilled (Unskilled) Migration Beneficial (Harmful) for the Host Country?, September 2006

1815 Eytan Sheshinski, Optimum Commodity Taxation in Pooling Equilibria, October 2006

1816 Gottfried Haber and Reinhard Neck, Sustainability of Austrian Public Debt: A Political Economy Perspective, October 2006

1817 Thiess Buettner, Michael Overesch, Ulrich Schreiber and Georg Wamser, The Impact of Thin-Capitalization Rules on Multinationals' Financing and Investment Decisions, October 2006

1818 Eric O’N. Fisher and Sharon L. May, Relativity in Trade Theory: Towards a Solution to the Mystery of Missing Trade, October 2006

1819 Junichi Minagawa and Thorsten Upmann, Labor Supply and the Demand for Child Care: An Intertemporal Approach, October 2006

1820 Jan K. Brueckner and Raquel Girvin, Airport Noise Regulation, Airline Service Quality, and Social Welfare, October 2006

1821 Sijbren Cnossen, Alcohol Taxation and Regulation in the European Union, October 2006

1822 Frederick van der Ploeg, Sustainable Social Spending in a Greying Economy with Stagnant Public Services: Baumol’s Cost Disease Revisited, October 2006

1823 Steven Brakman, Harry Garretsen and Charles van Marrewijk, Cross-Border Mergers \& Acquisitions: The Facts as a Guide for International Economics, October 2006 
1824 J. Atsu Amegashie, A Psychological Game with Interdependent Preference Types, October 2006

1825 Kurt R. Brekke, Ingrid Koenigbauer and Odd Rune Straume, Reference Pricing of Pharmaceuticals, October 2006

1826 Sean Holly, M. Hashem Pesaran and Takashi Yamagata, A Spatio-Temporal Model of House Prices in the US, October 2006

1827 Margarita Katsimi and Thomas Moutos, Inequality and the US Import Demand Function, October 2006

1828 Eytan Sheshinski, Longevity and Aggregate Savings, October 2006

1829 Momi Dahan and Udi Nisan, Low Take-up Rates: The Role of Information, October 2006

1830 Dieter Urban, Multilateral Investment Agreement in a Political Equilibrium, October 2006

1831 Jan Bouckaert and Hans Degryse, Opt In Versus Opt Out: A Free-Entry Analysis of Privacy Policies, October 2006

1832 Wolfram F. Richter, Taxing Human Capital Efficiently: The Double Dividend of Taxing Non-qualified Labour more Heavily than Qualified Labour, October 2006

1833 Alberto Chong and Mark Gradstein, Who's Afraid of Foreign Aid? The Donors' Perspective, October 2006

1834 Dirk Schindler, Optimal Income Taxation with a Risky Asset - The Triple Income Tax, October 2006

1835 Andy Snell and Jonathan P. Thomas, Labour Contracts, Equal Treatment and WageUnemployment Dynamics, October 2006

1836 Peter Backé and Cezary Wójcik, Catching-up and Credit Booms in Central and Eastern European EU Member States and Acceding Countries: An Interpretation within the New Neoclassical Synthesis Framework, October 2006

1837 Lars P. Feld, Justina A.V. Fischer and Gebhard Kirchgaessner, The Effect of Direct Democracy on Income Redistribution: Evidence for Switzerland, October 2006

1838 Michael Rauscher, Voluntary Emission Reductions, Social Rewards, and Environmental Policy, November 2006 